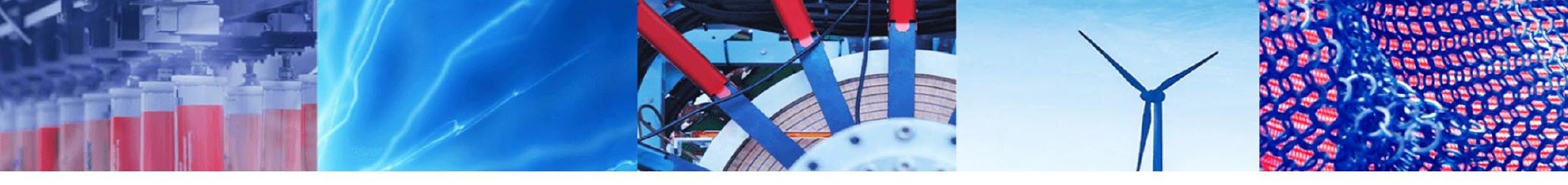

Research Article

\title{
Assessing the impact of vegetation coverage ratio in a floating water treatment bed of Pistia stratiotes
}

\author{
Kundan Samal $^{1} \cdot$ Soham Kar ${ }^{1} \cdot$ Shivanshi Trivedi ${ }^{1} \cdot$ Sudhanshu Upadhyay ${ }^{1}$
}

Received: 22 August 2020 / Accepted: 30 December 2020 / Published online: 12 January 2021

(C) The Author(s) 2021 OPEN

\begin{abstract}
Floating bed (FB) is one of the low cost and efficient system to treat polluted water bodies in rural as well as urban area. It requires less space compared to other macrophyte based treatment system. Vegetation coverage is an effective factor as atmospheric oxygen diffusion to water body depends upon this. When a water body is fully covered by vegetation, it prevents the diffusion of atmospheric oxygen, which is a major source of dissolved oxygen (DO). An optimum vegetation coverage is necessary to obtain maximum treatment efficiency and to verify this a laboratory scale experiment was performed with various vegetation coverage ratio (VCR) of $0,0.25,0.5,0.75,1$. Organics and nutrient removal were measured corresponding to initial floating bed VCR. COD removal for VCR 1.0, 0.75, 0.5, 0.25 and 0 were 86.4\%, 93.6\%, $96.2 \%, 85.4 \%$ and $60.8 \%$, respectively. The roots of macrophyte (Pistia stratiotes) supports growth of microorganism, which perform biodegradation of organics as well as uptake nutrients. Maximum $\mathrm{NH}_{4}{ }^{+}-\mathrm{N}_{\text {and }} \mathrm{PO}_{4}{ }^{3-}-\mathrm{P}$ removal were observed at VCR of 0.75 and 1.0 , respectively. In the tanks with VCR of $0.25,0.5$ and 0.75 , the final DO was more than $4 \mathrm{mg} / \mathrm{L}$, which is the requisite $D O$ value for survival of aquatic organism.
\end{abstract}

Keywords Vegetation coverage ratio (VCR) - Pistia stratiotes - Water body · Chemical oxygen demand - Dissolved oxygen (DO) · Floating bed (FB)

\section{Introduction}

Rapid urbanization, uncontrolled population growth, climate change and industrial development are the major reasons of high wastewater generation. The discharge from various industries and surface runoff maximize the addition of nutrients, heavy metals, organics and other chemical pollutants to fresh water bodies/lake and transform those to polluted one [1]. Increase in organic content raise the BOD and COD value of water body. Addition of nitrogen and phosphorous from agricultural fields to water body causes eutrophication. In eutrophied water, growth of phytoplankton is uncontrolled, which degrade the water quality by consuming all dissolved oxygen (DO). Low amount of DO hampers the aquatic life and results in the death of aquatic organisms [2]. Some phytoplankton species like cyanobacteria and blue green algae (BGA) have toxic effect which will be very much harmful if grows in water body. Death of phytoplankton release low molecular weight carbon in the water body which is untreatable by conventional treatment process. Residual carbon helps in regrowth of bacterial species in water distribution system [3].

Usage of floating bed to decontaminate water body (nutrient, organic and heavy metals rich water) is an innovative method and is low cost, easy to handle, sustainable treatment technology. The roots of the aquatic plants do not touch the bottom of the water body, so are forced to uptake nutrient directly from water column [4]. Aquatic macrophytes are contained a lot of aerenchyma tissue in

Kundan Samal, kundan.samalfce@kiit.ac.in | 'School of Civil Engineering, KIIT Deemed To Be University, Bhubaneswar 751024, Odisha, India. 
their roots and rhizomes, which enhance their buoyancy potential and float in the water. It reduces the growth of phytoplankton by competing for nutrient and sunlight. The hanging root structure provides surface area for the growth of microbes and enhance the contact period with contaminants. Ultimately, it regulates the lake biological structure and restores polluted water [5]. Plants need to be harvested periodically and in case of failure, there is chance of return of nutrients to the water after their decomposition. Harvested plants can be used as animal feed, raw materials for biofuel production and fertilizer, etc. The system has already been used in treatment of river water, piggery effluent, dairy wastewater, sewage, pond water, storm water, acid mine drainage, leachate, etc. [6-10]. Although several methods like precipitation, adsorption, flocculation, ion-exchange, etc. are available for the treatment of polluted water body, most of them fails to provide satisfactory results and affect their biological, physico-chemical characteristics [11]. Therefore, the present method is a suitable one in terms of treatment, cost, handling and installation.

Constant exposure of sunlight to water body reduces the growth of phytoplankton, and diffusion of atmospheric oxygen to water maintains adequate dissolved oxygen. Both sunlight penetration and dissolved oxygen are responsible for the purification of water and its value depends on the vegetation coverage area on water surface. So, the major objective of the study is to evaluate the effect of vegetation coverage ratio on the removal of organic and nutrient in a water body using floating plant.

\section{Materials and Methodology}

\subsection{Tank design}

Five circular tanks were designed made up of plastic materials with height $0.4 \mathrm{~m}$ and diameter $0.5 \mathrm{~m}$ as shown in Fig. 1. Bottom of the tank was filled with gravel and soil up to $5-\mathrm{cm}$ height for the purpose of sediment. Raw wastewater was added to the tank up to $0.3 \mathrm{~m}$ excluding bottom $5 \mathrm{~cm}$ of soil. Aquatic macrophyte $P$. stratiotes was added to the wastewater in the tank which were collected from a pond situated at Balianta $\left(20.3085^{\circ} \mathrm{N}\right.$ and $\left.85.8866^{\circ} \mathrm{E}\right)$, Bhubaneswar (Odisha). The plants were collected with the pond water in the polythene bags and immediately brought to the laboratory. All the plants were of same size and at same growth stage. The roots of the sampled plants were washed carefully with distilled water to remove any adhering mud or dirt. The plants were acclimatized for 15 days by placing them in tap water without addition of any nutrients under sunlight to let them adapt to the new environment. Experiment was performed for another 30 days after acclimatization period. Initially, various vegetation coverage ratio $(0,0.25,0.50,0.75,1)$ were maintained in the system as shown in Fig. 2. P. stratiotes (Water lettuce) is a small, free floating evergreen perennial plant with feathery roots, which can reach up to $30 \mathrm{~cm}$ in depth. The fleshy leaves of this plant are arranged in a rosette and measure $2 \mathrm{~cm}-10 \mathrm{~cm}$ in length. The plant can spread quickly, especially in still water, to form quite extensive clumps. The optimal growth temperature range for the plant is $22^{\circ} \mathrm{C}-30^{\circ} \mathrm{C}$ [12].
Fig. 1 Floating bed reactor design
Pistia stratiotes

(Floating aquatic plant)

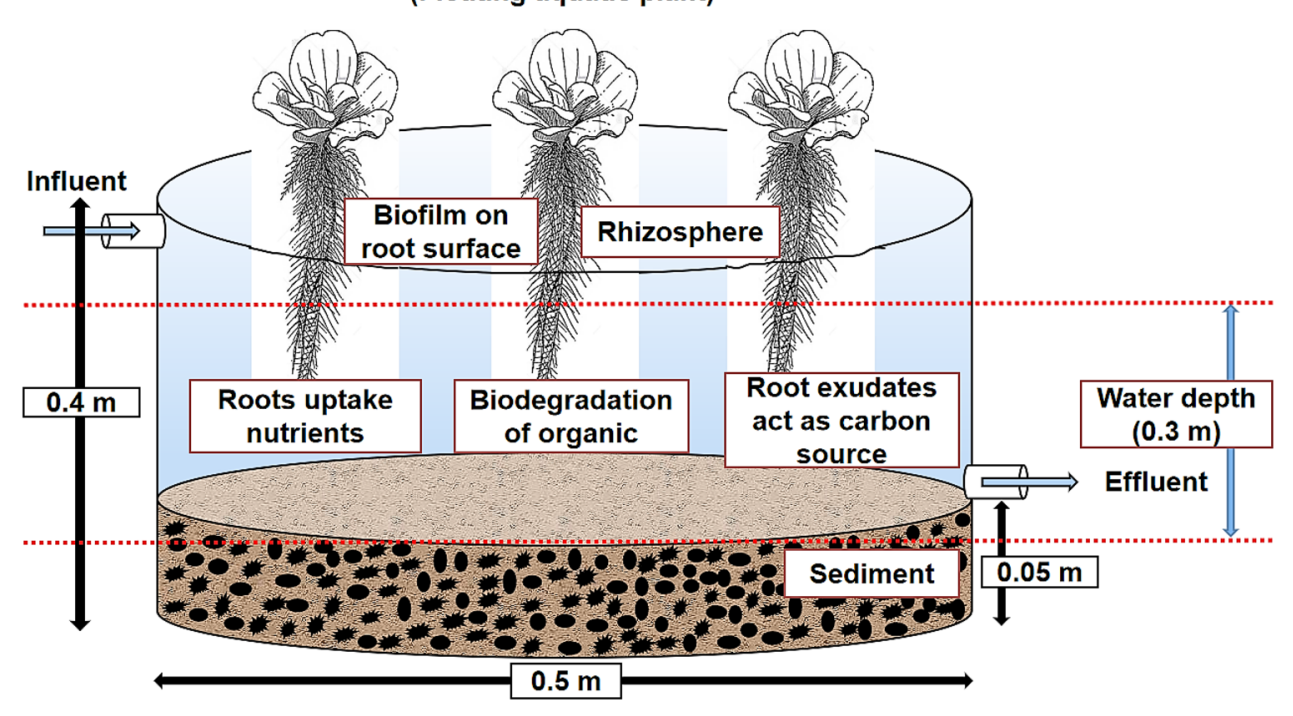

SN Applied Sciences 


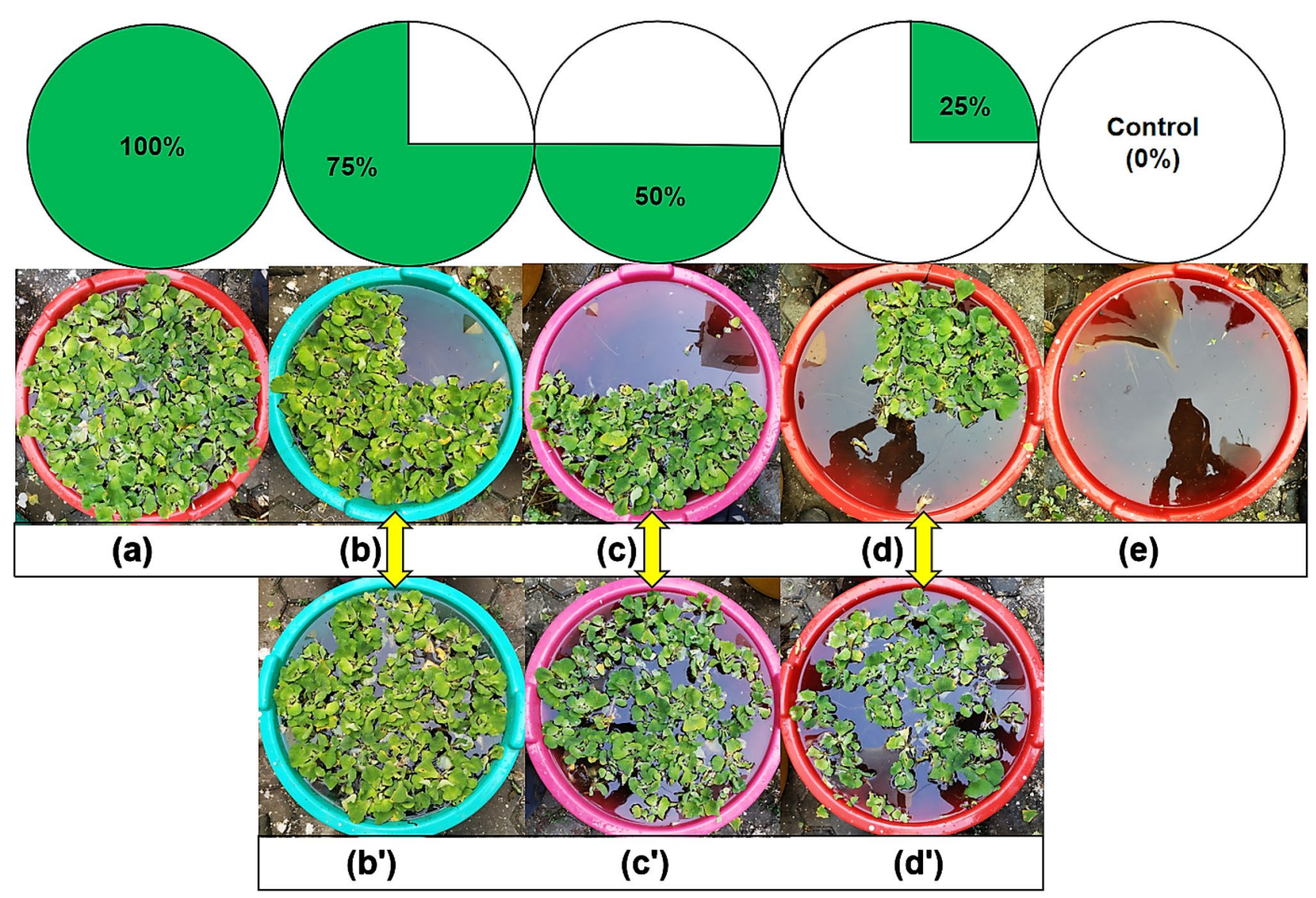

Fig. 2 Vegetation coverage ratio a $100 \%$, b $75 \%$, c $50 \%$, d $25 \%$, e $0 \%$ and various coverage ratio after scattering of vegetation. b' $75 \%$, c' $50 \%$, d' $25 \%$

\subsubsection{Wastewater composition}

Synthetic domestic wastewater was prepared by addition of sucrose, $\mathrm{KH}_{2} \mathrm{PO}_{4}, \mathrm{NaHCO}_{3}, \mathrm{NH}_{4} \mathrm{Cl}, \mathrm{MgSO}_{4}, \mathrm{KNO}_{3}$, $\mathrm{CaCl}_{2}, \mathrm{MnSO}_{4}, \mathrm{H}_{3} \mathrm{BO}_{3}$ in tap water [13]. Wastewater initially contain $\mathrm{COD}, \mathrm{PO}_{4}{ }^{3-}-\mathrm{P}, \mathrm{NH}_{4}{ }^{+}-\mathrm{N}, \mathrm{NO}_{3}{ }^{-}-\mathrm{N}$ of 500,25 , $28,12 \mathrm{mg} \mathrm{L}^{-1}$, respectively, and analysis was performed in every 3 days.

\subsubsection{Analytical Procedure}

Wastewater was analysed for $\mathrm{COD}, \mathrm{PO}_{4}{ }^{3-}-\mathrm{P}, \mathrm{NH}_{4}{ }^{+}-\mathrm{N}$, $\mathrm{NO}_{3}{ }^{-} \mathrm{N}, \mathrm{pH}, \mathrm{DO}$ [14]. Efficiency was calculated using following formula:

$\operatorname{Efficiency}(\%)=\frac{C_{i}-C_{o}}{C_{i}} \times 100$

where $C_{i}$ and $C_{0}$ are influent and effluent value, respectively.

\section{Results and discussion}

\subsection{Pollutants removal mechanism in EFB}

Some aquatic plants float in the water due to the presence of aerenchyma tissue, which provides sufficient buoyancy force to remain in floating condition. The roots remain in hanging condition below water level and create a mesh like structure. Young roots excrete some amount of oxygen to the water body, which is absorbed by the leaves from the atmosphere [15, 37]. The water surrounded to the root mesh remains oxygenated becoming favorable for the growth of aerobic bacteria. The root provides sufficient surface area for the attachment and colonization of various microorganisms. Roots also release different exudates like citrate, oxalate, amino acid, malate, etc., which act as a carbon source for the microbes and helps in their stimulation and proliferation [16, 24-26, 38]. As the microbial population increases, the biofilm layer becomes sticky in nature. Organic and solid particle present in wastewater 
attached to the biofilm layer under water and degraded by microorganism aerobically. Diffusion of atmospheric oxygen to the water body is one of the major sources of oxygen to maintain aerobic condition under water [27-29, 39]. When water surface is fully covered by plants, transfer of atmospheric oxygen ceases and creates anoxic condition, which is unfavorable for the growth of aerobic microbes. Sunlight is not able to pass through the water body and photosynthetic microbes starts to disappear. Non photosynthetic bacteria starts to dominate the microbial colony and DO amount declines gradually [17]. It is necessary to maintain a fraction of open water surface rather than fully vegetation coverage to improve treatment process. In the present experiment when vegetation coverage ratio were $0,0.25,0.5,0.75$ and 1, COD removal were $60.8 \%, 85.4 \%$, $96.2 \%, 93.6 \%$ and $88.4 \%$, respectively (Fig. 3a). In the tank with no vegetation, $C O D$ removal was due to microbes present in soil/sediment. Maximum 96.2\% COD was removed when initial vegetation coverage was 0.5 . Atmospheric oxygen diffused to water body effectively and sunlight passes through water due to open water surface. Oxygen released from plant roots and diffused atmospheric oxygen together maintained aerobic condition and treated water efficiently [30-32]. In case of coverage ratio 1, COD removal was $88.4 \%$ and it was due to insufficient diffusion of atmospheric oxygen to water, and vegetation layer prevented the diffusion process. In all the tanks, COD amount decreases constantly. Zimmels et al. (2006) [23] observed $88.89 \%$ COD reduction using $P$. stratiotes at an influent COD concentration of $450 \mathrm{mg} / \mathrm{L}$. Mukherjee et al. (2015) [12] reported COD, $\mathrm{NH}_{4}-\mathrm{N}, \mathrm{NO}_{3}-\mathrm{N}$ and TP removal of $65 \%$, $65 \%, 98 \%, 70 \%$, respectively during treatment of rice mill wastewater using P. stratiotes. Sudiarto et al. (2019) [10] found TN removal of $82.12 \%$ and TP removal of $42.78 \%$, while treating swine wastewater using $P$. stratiotes. Kumar and Deswal (2020) [22] treated rice mill wastewater with aquatic plant $P$. stratiotes and observed a TP removal of $80.04 \%$ and COD removal of $74.53 \%$.

In the tank with coverage ratio 0.25 and 1 , final DO value was $4.7 \mathrm{mg} / \mathrm{L}$ and $3.3 \mathrm{mg} / \mathrm{L}$, respectively (Fig. $4 \mathrm{a}$ ). In all the tanks with vegetation, DO value was increased up to 15 days and it was due to effective addition of extra
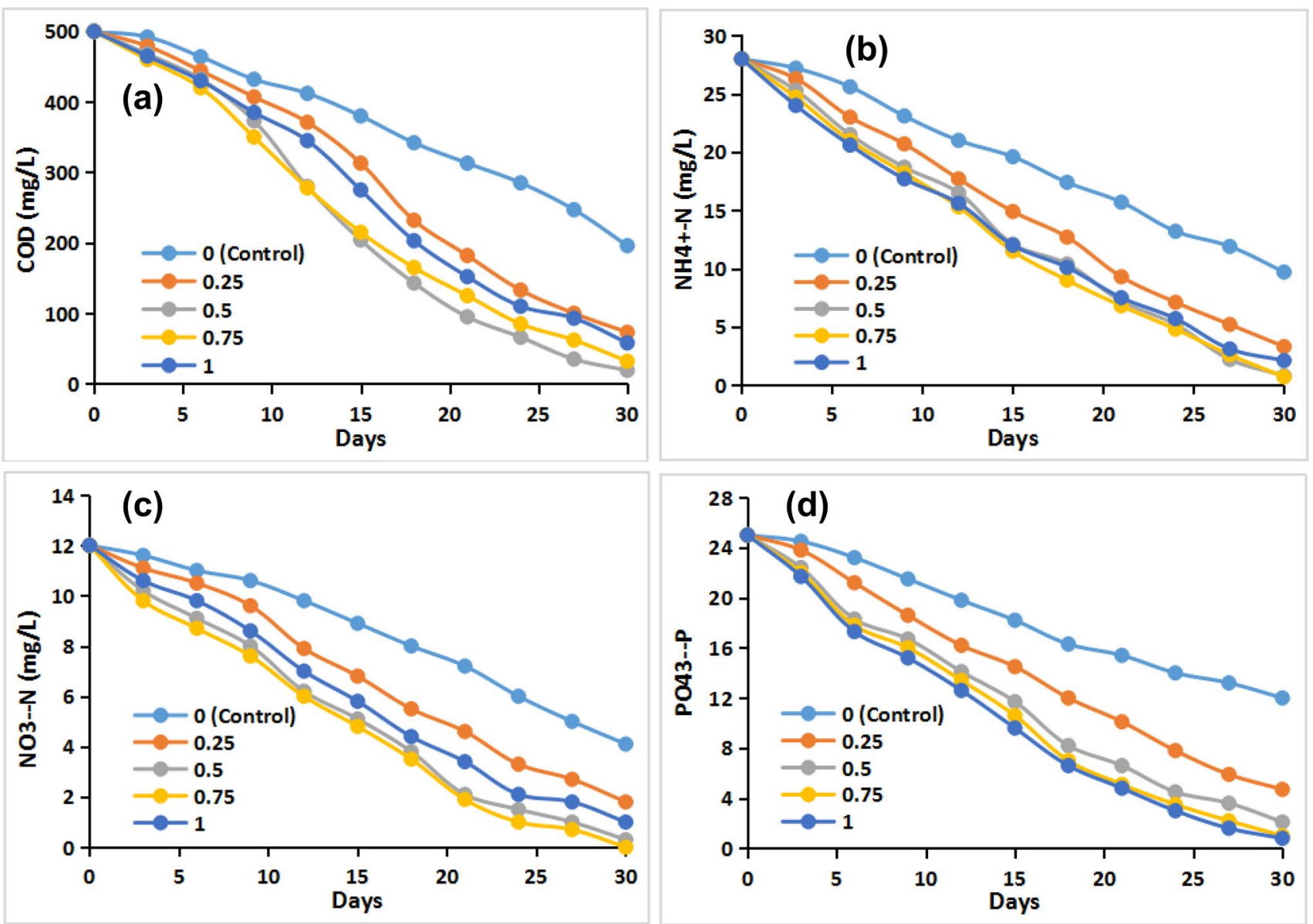

Fig. 3 Removal of a COD, $\mathbf{b} \mathrm{NH}_{4}{ }^{+}-\mathrm{N}, \mathbf{c ~ N O}_{3}{ }^{-}-\mathrm{N}$ and $\mathbf{d} \mathrm{PO}_{4}{ }^{3-}-\mathrm{P}$ in Floating bed 

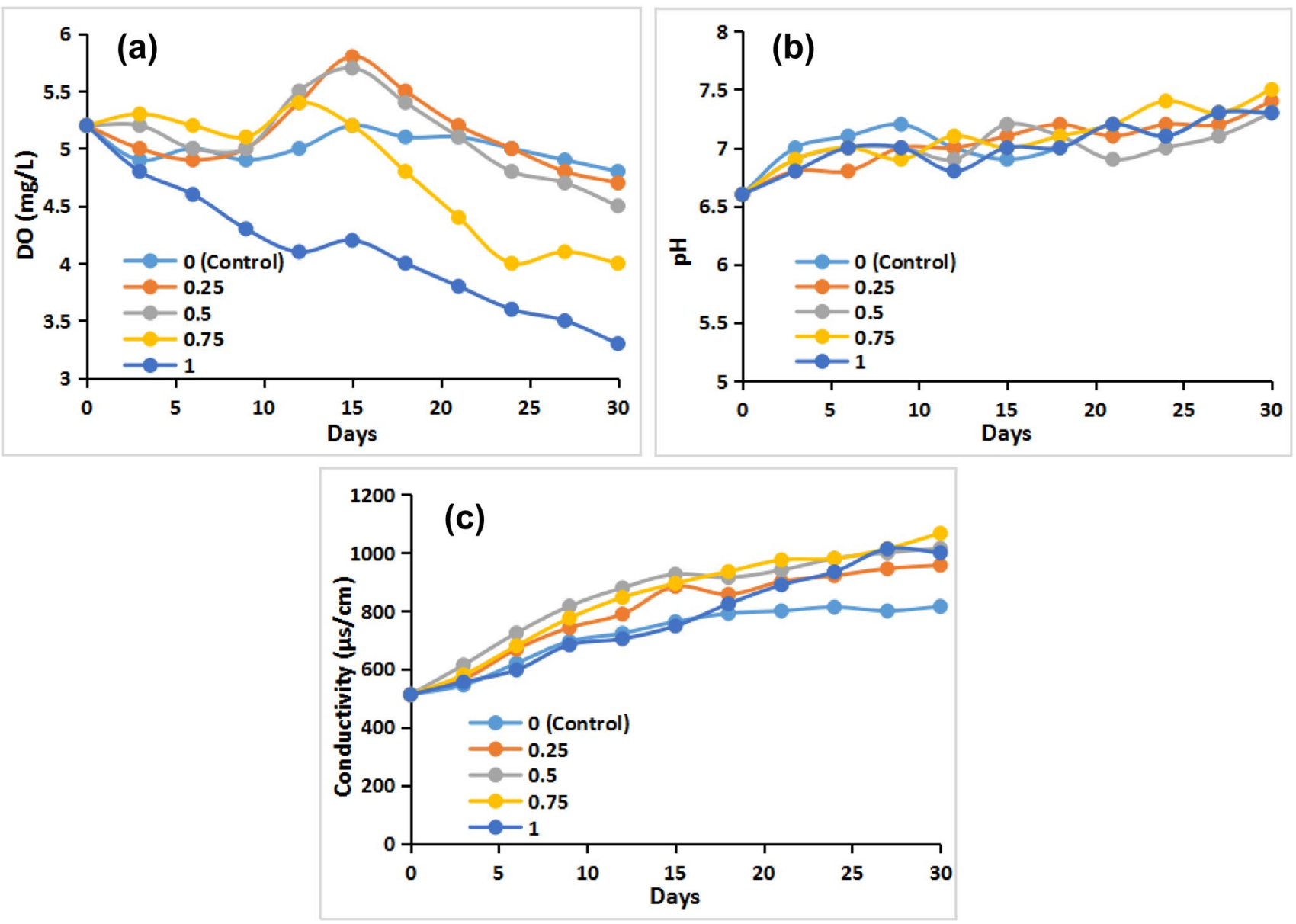

Fig. 4 Characteristics of wastewater in floating bed; a DO, $\mathbf{b}$ pH, c Conductivity

oxygen from the roots apart from diffusion [18]. Vegetation coverage in all the tanks (except control) were increased after 15 days, so preventing atmospheric oxygen diffusion. So, the DO value gradually reduced after 15 days of the start of the experiment. At the end of the experiment, control tank had highest DO of $4.8 \mathrm{mg} / \mathrm{L}$, which signifies that atmospheric oxygen diffusion process was dominant compare to root oxygen release. The initial coverage ratio also increased slowly due to growth of the plants as the experiment progressed. The open space in the tanks were covered by newly growing plants. Diffusion of atmospheric oxygen to the water was reduced due to formation of new plant layer, however, release of root oxygen was increased [33,34]. The DO value of water depends upon resultant contribution of atmospheric oxygen diffusion and root oxygen release. As the experiment progressed, vegetation coverage also increased significantly. At the end of the experimental process, the final VCR was $0.6,0.95$ and 1 for the tanks having initial VCR of $0.25,0.5$ and 0.75 , respectively (Fig. 5). Number of plants increased in the tank with VCR 1 making the system denser

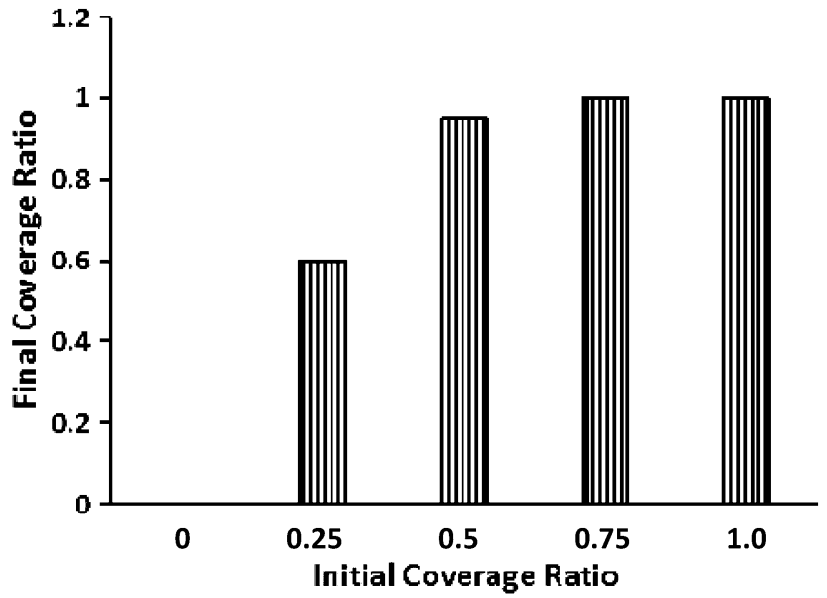

Fig. 5 Increase in vegetation coverage ratio at the end of the experiment after treatment process

and completely preventing diffusion of atmospheric oxygen. Table 1 shows the values of various physico-chemical values during experiments. 
Table 1 Values of physicochemcial parameter during experiment

\begin{tabular}{|c|c|c|c|c|c|c|}
\hline \multirow[t]{2}{*}{ Parameter } & \multirow[t]{2}{*}{ Days } & \multicolumn{5}{|c|}{ Vegetation coverage ratio (VCR) } \\
\hline & & 0 (control) & 0.25 & 0.5 & 0.75 & 1 \\
\hline \multirow[t]{3}{*}{$\mathrm{COD}(\mathrm{mg} / \mathrm{L})$} & 0 & 500 & 500 & 500 & 500 & 500 \\
\hline & 15 & 380 & 313 & 204 & 215 & 275 \\
\hline & 30 & 196 & 73 & 19 & 32 & 58 \\
\hline \multirow[t]{3}{*}{$\mathrm{NH}_{4}^{+}-\mathrm{N}(\mathrm{mg} / \mathrm{L})$} & 0 & 28 & 28 & 28 & 28 & 28 \\
\hline & 15 & 19.6 & 14.9 & 12.1 & 11.5 & 12 \\
\hline & 30 & 9.7 & 3.3 & 0.8 & 0.7 & 2.1 \\
\hline \multirow[t]{3}{*}{$\mathrm{NO}_{3}{ }^{-}-\mathrm{N}(\mathrm{mg} / \mathrm{L})$} & 0 & 12 & 12 & 12 & 12 & 12 \\
\hline & 15 & 8.9 & 6.8 & 5.1 & 4.8 & 5.8 \\
\hline & 30 & 4.1 & 1.8 & 0.3 & 0 & 1 \\
\hline \multirow[t]{3}{*}{$\mathrm{PO}_{4}{ }^{3-}-\mathrm{P}(\mathrm{mg} / \mathrm{L})$} & 0 & 25 & 25 & 25 & 25 & 25 \\
\hline & 15 & 18.2 & 14.5 & 11.7 & 10.6 & 9.6 \\
\hline & 30 & 12 & 4.7 & 2.1 & 1 & 0.8 \\
\hline \multirow[t]{3}{*}{ DO (mg/L) } & 0 & 5.2 & 5.2 & 5.2 & 5.2 & 5.2 \\
\hline & 15 & 5.2 & 5.8 & 5.7 & 5.2 & 4.2 \\
\hline & 30 & 4.8 & 4.7 & 4.5 & 4 & 3.3 \\
\hline \multirow[t]{3}{*}{$\mathrm{pH}$} & 0 & 6.6 & 6.6 & 6.6 & 6.6 & 6.6 \\
\hline & 15 & 6.9 & 7.1 & 7.2 & 7 & 7 \\
\hline & 30 & 7.3 & 7.4 & 7.3 & 7.5 & 7.3 \\
\hline \multirow[t]{3}{*}{ Conductivity $(\mu \mathrm{s} / \mathrm{cm})$} & 0 & 512 & 512 & 512 & 512 & 512 \\
\hline & 15 & 763 & 884 & 926 & 895 & 748 \\
\hline & 30 & 815 & 957 & 1015 & 1067 & 1000 \\
\hline
\end{tabular}

Nitrogen removed by microbes and plant assimilation, ammonia volatilization, nitrification-denitrification in EFB $[19,36]$. Some microorganisms (bacteria, algae, fungi) accumulate $\mathrm{NH}_{4}{ }^{+}-\mathrm{N}$ and $\mathrm{NO}_{3}{ }^{-}-\mathrm{N}$ in their body and plant also uptake same for their growth. In volatilization process, some amount of ammonia also vaporized to atmosphere. The combination of nitrification and denitrification removed most of the nitrogen fraction from wastewater. In aerobic condition nitrification occurred, and ammonia and organic nitrogen oxidized to nitrate, whereas denitrification occurred in anoxic condition resulting release of nitrogen gas to the atmosphere [20]. Bottom level of the tank usually maintained anoxic condition as atmospheric oxygen not able to diffuse much deeper facilitating the growth of denitrifying bacteria; Bacillus, Neisseria, Pseudomonas, etc. [19]. Since the top water contains diffused atmospheric oxygen is aerobic in nature and promote nitrification. In the present study nitrogen present in the form of ammonia (also nitrate), which may oxidize to nitrate and again it (nitrate) reduced to $\mathrm{N}_{2}$ gas. In volatilization process some amount of ammonia is also vaporized to atmosphere [10]. In the tank with vegetation coverage ratio $0,0.25,0.5,0.75$ and $1, \mathrm{NH}_{4}{ }^{+}-\mathrm{N}$ removal were $65.3 \%$, $88.2 \%, 97.1 \%, 97.5 \%$ and $92.5 \%$, respectively (Fig. 3 b). Similarly, $\mathrm{NO}_{3}{ }^{-}-\mathrm{N}$ concentration were $4.1,1.8,0.3,0,1$ in tank with coverage ratio $0,0.25,0.5,0.75,1$, respectively
(Fig. 3C). In nitrification process some amount of $\mathrm{NH}_{4}{ }^{+}-\mathrm{N}$ is also converted in to the nitrate form and remains in water.

Orthophosphate $\left(\mathrm{PO}_{4}{ }^{3-}-\mathrm{P}\right)$ directly uptake by microbes and plants. Plant accumulation depends upon their growth rate, tissue type and uptake capacity. Plants having higher growth rate will accumulate more phosphorous [7]. Some amount of phosphorous may adsorb to the sediment. Maximum $96.8 \%$ phosphorous was removed in tank with coverage ratio 1 . In the tank with coverage ratio 0 , $0.25,0.5$ and $0.75, \mathrm{PO}_{4}{ }^{3-}-\mathrm{P}$ removal was $52 \%, 81.2 \%, 91.6 \%$ and $96 \%$, respectively (Fig. $3 d$ ).

The initial and final $\mathrm{pH}$ of the water sample in all the tanks was 6.6 and 7.2-7.6, respectively (Fig. 4b). The final conductivity in the effluents of all the tanks was in the range of $815 \mu \mathrm{s} / \mathrm{cm}-1067 \mu \mathrm{s} / \mathrm{cm}$ (Fig. 4c). The conductivity increase from an initial conductivity of $512 \mu \mathrm{s} / \mathrm{cm}$ due to microbial degradation of pollutants and their transform to ionic form.

\subsection{COD removal kinetics}

Biodegradation of organics follow the first order reaction kinetics. According to the relation between effluent concentration and hydraulic retention time (HRT), graph of $\mathrm{InC}_{\text {out }}$ versus t (days) was plotted, and kinetic coefficients (k) was obtained [21]. 

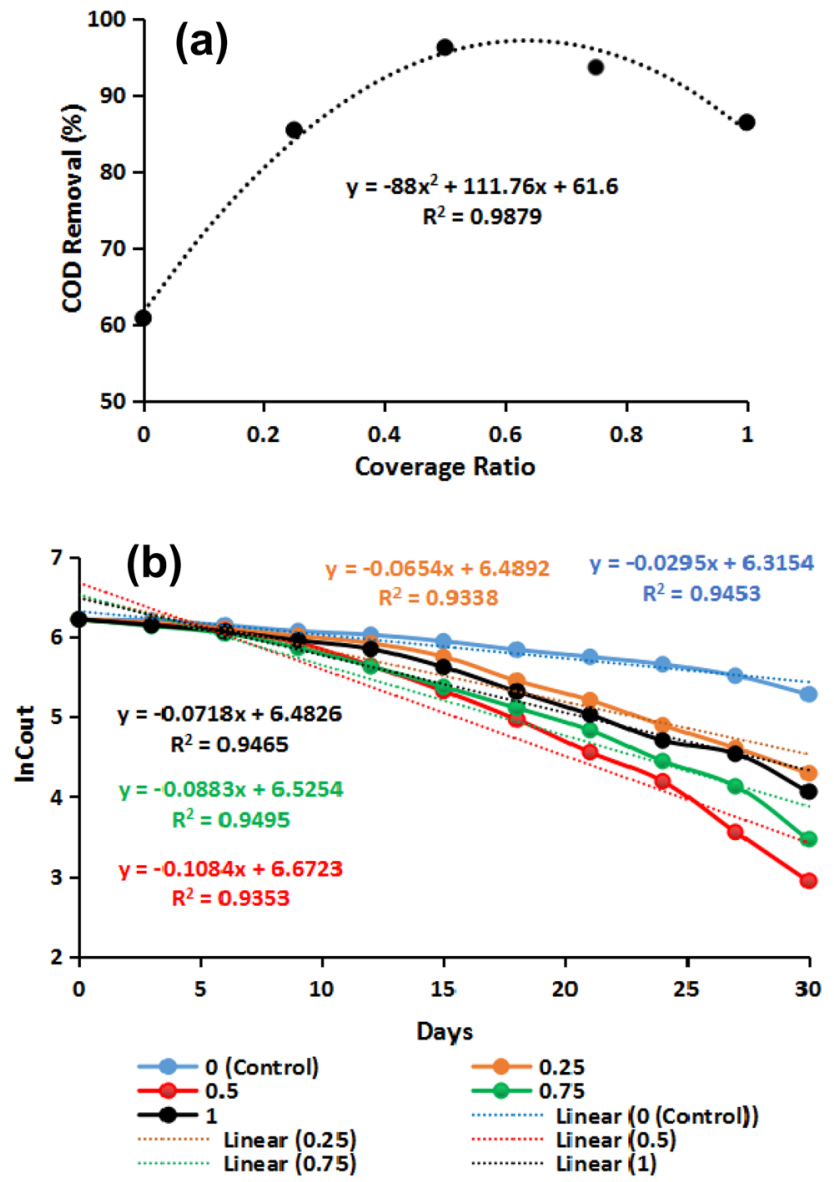

Fig. 6 Reaction kinetic equation of COD degradation in floating bed

First order; $\ln \cdot \frac{C_{\text {out }}}{C_{\text {in }}}=-k t$

where $\mathrm{k}=$ reaction rate constant $\left(\mathrm{d}^{-1}\right)$.

The correlation coefficients $\left(R^{2}\right)$ of the first order kinetic equations in all the tanks were above 0.93 , which showed that kinetic simulation in floating bed can well exhibit the laws of organic pollutants degradation in each system, i.e., the efficiency of organic matter processing in each floating bed tank increased gradually with the extension of the hydraulic retention time (Fig. 6b).

With increase in vegetation coverage ratio COD removal efficiency also increased. Maximum 96.2\% COD removal was observed at an initial vegetation coverage ratio of 0.5 (Fig. 6a). The order of COD removal with respective to vegetation coverage ratio was $0.5(96.2 \%)>0.75(93.6 \%)>1.0$ $(86.4 \%)>0.25(85.4 \%)>0(60.8 \%)$. A second order polynomial equation was designed considering COD removal (\%) and coverage ratio and the $R^{2}$ value obtained was 0.98 (Fig. 6a). When the coverage ratio was more than 0.5, COD removal efficiency (\%) was decreasing gradually.

\section{Conclusions}

FB is one of the eco-friendly and sustainable technologies for the treatment of various types of wastewater in which organic material is removed by biodegradation and nutrient uptake by plants. In this system, vegetation coverage plays a major role in treatment process as it affects atmospheric oxygen diffusion. When vegetation coverage ratio (VCR) increases, diffusion of atmospheric oxygen to the water body decreases, which reduces biodegradation of organic pollutants present in wastewater. So, there should be an optimum VCR for maximum removal of organics and in this study the optimum value was 0.5. Maximum 96.8\% $\mathrm{PO}_{4}{ }^{3-}-\mathrm{P}$ and $97.5 \% \mathrm{NH}_{4}{ }^{+}-\mathrm{N}$ were removed in tank with coverage ratio of 1 and 0.75 , respectively. COD removal was following first order kinetics and in all the tanks correlation coefficients were above 0.93 . Apart from vegetation coverage ratio, water depth and types of macrophyte species also affect the treatment process.

Acknowledgements The authors express their gratitude to the School of Civil Engineering, KIIT Deemed to be University for providing necessary facilities to carry out this research work.

\section{Compliance with ethical standards}

Conflict of interest The author declare that they have no competing interests.

Open Access This article is licensed under a Creative Commons Attribution 4.0 International License, which permits use, sharing, adaptation, distribution and reproduction in any medium or format, as long as you give appropriate credit to the original author(s) and the source, provide a link to the Creative Commons licence, and indicate if changes were made. The images or other third party material in this article are included in the article's Creative Commons licence, unless indicated otherwise in a credit line to the material. If material is not included in the article's Creative Commons licence and your intended use is not permitted by statutory regulation or exceeds the permitted use, you will need to obtain permission directly from the copyright holder. To view a copy of this licence, visit http://creativecommons .org/licenses/by/4.0/.

\section{References}

1. Cao W, Zhang Y (2014) Removal of nitrogen (N) from hypereutrophic waters by ecological floating beds (EFBs) with various substrates. Ecol Eng 62:148-152

2. Gao L, Zhou W, Wu S, He S, Huang J, Zhang X (2018) Nitrogen removal by thiosulfate-driven denitrification and plant uptake in enhanced floating treatment wetland. Sci Tot Environ 621:1550-1558

3. Brix H, Sorrell BK, Orr PT (1992) Internal pressurization and convective gas flow in some emergent freshwater macrophytes. Limnol Oceanog 37:1420-1433 
4. Geng Y, Han W, Yu C, Jiang Q, Wu J, Chang J, Ge Y (2017) Effect of plant diversity on phosphorus removal in hydroponic microcosms simulating floating constructed wetlands. Ecol Eng 107:110-119

5. Headley TR, Tanner CC (2012) Constructed wetlands with floating emergent macrophytes: an innovative stormwater treatment technology. Crit Rev Environ Sci Technol 42:2261-2310

6. Hu Z, Li D, Guan D (2019) Water quality retrieval and algae inhibition from eutrophic freshwaters with iron-rich substrate based ecological floating beds treatment. Sci Tot Environ 712:135584

7. Pavlineri N, Skoulikidis NT, Tsihrintzis VA (2017) Constructed floating wetlands: a review of research, design, operation and management aspects, and data meta-analysis. Chem Eng J 308:1120-1132

8. Samal K, Kar S, Trivedi S (2019) Ecological floating bed (EFB) for decontamination of polluted water bodies: Design, mechanism and performance. J Environ Manage 251:109550

9. Song J, Li Q, Dzakpasu M, Wang XC, Chang N (2020) Integrating stereo-elastic packing into ecological floating bed for enhanced denitrification in landscape water. Bioresourc Technol 299:122601

10. Sudiarto SIA, Renggaman A, Choi HL (2019) Floating aquatic plants for total nitrogen and phosphorus removal from treated swine wastewater and their biomass characteristics. J Environ Manag 231:763-769

11. Samal K, Dash RR, Bhunia P (2018) Development and optimization of two stage macrophyte assisted vermifilter for the treatment of dairy wastewater. Sci Tot Environ 645:156-169

12. Mukherjee B, Majumdar M, Gangopadhyay A, Chakraborty S, Chaterjee D (2015) Phytoremediation of parboiled rice mill wastewater using water lettuce (Pistia Stratiotes). Int J Phytoremediation 17:651-656

13. Miao MS, Yao XD, Shu L, Yan YJ, Wang Z, Li N, Cui XT, Lin YM, Kong Q (2016) Mixotrophic growth and biochemical analysis of Chlorella vulgaris cultivated with synthetic domestic wastewater. Int Biodet \& Biodegrad 113:120-125

14. APHA (2005) Standard methods for the examinations of water and wastewater, 21 st edn. APHA and AWWA and WEF, Washington

15. Vymazal J (2007) Removal of nutrients in various types of constructed wetlands. Sci Tot Environ 380:48-65

16. Samal K, Dash RR, Bhunia P (2017) Treatment of wastewater by vermifiltration integrated with macrophyte filter: a review. J Environ Chem Eng 5:2274-2289

17. Zhao F, Xi S, Yang X, Yang W, Li J, Gu B, He Z (2012) Purifying eutrophic river waters with integrated floating island systems. Ecol Eng 40:53-60

18. Armstrong W, Cousins D, Armstrong J, Turner DW, Beckett PM (2000) Oxygen distribution in wetland plant roots and permeability barriers to gas-exchange in the rhizosphere: a microelectrode and modelling study with Phragmites australis. Ann Bot 86:687-703

19. Zhang L, Sun Z, Xie J, Wub J, Cheng S (2018) Nutrient removal, biomass accumulation and nitrogen-transformation functional gene response to different nitrogen forms in enhanced floating treatment wetlands. Ecol Eng 112:21-25

20. Zhou X, Wang G (2010) Nutrient concentration variations during Oenanthe javanica growth and decay in the ecological floating bed system. J Environ Sci 22:1710-1717

21. Kumar T, Hari Prasad KS, Singh NK (2016) Substrate removal kinetics and performance assessment of a vermifilter bioreactor under organic shock load conditions. Wat Sci and Tech 74:1177-1184

22. Kumar S, Deswal S (2020) Phytoremediation capabilities of Salvinia molesta, water hyacinth, water lettuce, and duckweed to reduce phosphorus in rice mill wastewater. Int J Phytorem 22:1097-1109

SN Applied Sciences

APRINGER NATURE journa
23. Zimmels Y, Kirzhner F, Malkovskaja A (2006) Application of Eichhornia crassipes and Pistia stratiotes for treatment of urban sewage in Israel. J Environ Manage 81:420-428

24. Afzal M, Arslan M, Müller JA, Shabir G, Islam E, Tahseen R, Anwarul-Haq M, Hashmat AJ, lqbal S, Khan QM (2019) Floating treatment wetlands as a suitable option for large-scale wastewater treatment. Nat Sustain 2:863-871

25. Samal K, Trivedi S (2020) A statistical and kinetic approach to develop a floating bed for the treatment of wastewater. J Environ Chem Eng 5:104102

26. Afzal M, Rehman K, Shabir G, Tahseen R, ljaz A, Hashmat AJ, Brix $\mathrm{H}$ (2019) Large-scale remediation of oil-contaminated water using floating treatment wetlands. NPJ CI Wat 2:3

27. Fahid M, Arslan M, Shabir G, Younus S, Yasmeen T, Rizwan M, Siddique K, Ahmad SR, Tahseen R, Ali SIS, Afzal M (2020) Phragmites australis in combination with hydrocarbons degrading bacteria is a suitable option for remediation of diesel-contaminated water in floating wetlands. Chemosphe 240:124890

28. Rehman K, ljaz A, Arslan M, Afzal M (2019) Floating treatment wetlands as biological buoyant filters for wastewater reclamation. Int J Phyt 21:1273-1289

29. Shahid MJ, Siddique M, Ali S, Tahseen R, Afzal M (2019) Potentialities of floating wetlands for the treatment of polluted water of river Ravi, Pakistan. Ecol Eng 133:167-176

30. Samal K, Dash RR, Bhunia P (2018) A comparative study of macrophytes influence on performance of hybrid vermifilter for wastewater treatment. J Environ Chem Eng 6:4714-4726

31. Tara N, Arslan M, Hussain Z, Iqbal M, Khan QM, Afzal M (2019) On-site performance of floating treatment wetland macrocosms augmented with dye-degrading bacteria for the remediation of textile industry wastewater. J Clean Prod 217:541-548

32. Rehman K, Imran A, Amin I, Afzal M (2018) Inoculation with bacteria in floating treatment wetlands positively modulates the phytoremediation of oil field wastewater. J Hazard Mat 349:242-251

33. Shahid MJ, Arslan M, Ali S, Siddique M, Afzal M (2018) Floating wetlands: a sustainable tool for wastewater treatment. C - Soil Air Wat 46:1800120

34. Ijaz A, lqbal Z, Afzal M (2016) Remediation of sewage and industrial effluent using bacterially-assisted floating treatment wetlands vegetated with Typha domingensis. Wat Sci Technol 74:2192-2201

35. Ijaz A, Shabir G, Khan QM, Afzal M (2015) Enhanced remediation of sewage effluent by endophyte-assisted floating treatment wetlands. Ecol Eng 84:58-66

36. Samal K, Yasmin N, Kumari P (2020) Challenges in the implementation of Phyto Fuel System (PFS) for wastewater treatment and harnessing bio-energy. J Environ Chem Eng 8:104388

37. Kumar V, Singh J, Chopra AK (2018) Assessment of plant growth attributes, bioaccumulation, enrichment, and translocation of heavy metals in water lettuce (Pistia stratiotes L.) grown in sugar mill effluent. Int J Phytorem 20:507-521

38. Kumar V, Singh J, Kumar P (2019) Heavy metal uptake by water lettuce (Pistia stratiotes L.) from paper mill effluent (PME): experimental and prediction modeling studies. Env Sci Pol Res 26:14400-14413

39. Kumar V, Singh J, Saini A, Kumar P (2019) Phytoremediation of copper, iron and mercury from aqueous solution by water lettuce (Pistia stratiotes L.). Environ Sustain 2:55-65

Publisher's Note Springer Nature remains neutral with regard to jurisdictional claims in published maps and institutional affiliations. 